\title{
Transmission Biology of Raspberry latent virus, the First Aphid-Borne Reovirus
}

\author{
Diego F. Quito-Avila, Danielle Lightle, Jana Lee, and Robert R. Martin
}

First and fourth authors: Department of Botany and Plant Pathology, and second and third authors: Entomology Program, Oregon State University, Corvallis 97331; and third and fourth authors: Horticultural Crops Research Laboratory, United States Department of Agriculture-Agricultural Research Service, Corvallis, OR 97331. Accepted for publication 27 January 2012.

\begin{abstract}
Quito-Avila, D. F., Lightle, D., Lee, J., and Martin, R. R. 2012. Transmission biology of Raspberry latent virus, the first aphid-borne reovirus. Phytopathology 102:547-553.

Raspberry latent virus (RpLV) is a newly characterized reovirus found in commercial raspberry fields in the Pacific Northwest (PNW). Thus far, all members of the plant reoviruses are transmitted in a replicative, persistent manner by several species of leafhoppers or planthoppers. After several failed attempts to transmit RpLV using leafhoppers, the large raspberry aphid, commonly found in the PNW, was tested as a vector of the virus. The virus was transmitted to new, healthy raspberry plants when inoculated with groups of at least 50 viruliferous aphids, suggesting that aphids are vectors of $\mathrm{RpLV}$, albeit inefficient ones. Using absolute

and relative quantification methods, it was shown that the virus titer in aphids continued to increase after the acquisition period even when aphids were serially transferred onto fresh, healthy plants on a daily basis. Transmission experiments determined that RpLV has a 6-day latent period in the aphid before it becomes transmissible; however, it was not transmitted transovarially to the next generation. To our knowledge, this is the first report of a plant reovirus transmitted by an aphid. Phylogenetic analyses showed that RpLV is related most closely to but distinct from Rice ragged stunt virus (RRSV), the type member of the genus Oryzavirus. Moreover, the conserved nucleotide termini of the genomic segments of RpLV did not match those of RRSV or other plant reoviruses, allowing us to suggest that RpLV is probably the type member of a new genus in the Reoviridae comprising aphid-transmitted reoviruses.
\end{abstract}

Due to the stationary nature of their hosts, plant viruses rely on third parties in order to be transmitted from host to host, with the exception of those transmitted by pollen, seed, or mechanical means. Arthropods, fungi, and nematodes have been reported as the main vectors responsible for virus transmission in plants $(3,8)$. Insects in the order Hemiptera (aphids, whiteflies, and planthoppers) are by far the most common vectors within the phylum Arthropoda $(2,13,20,22)$. The transmission mechanism involves acquisition, retention, and inoculation of the virus into a new plant by a vector. The components involved in this process define an intricate and specific relationship between the plant, virus, and its vector. Therefore, virus transmission by a living vector is not a random mechanical process, and involves specific virus and host factors $(10,25,45,46)$. Accordingly, the virus-vector specificity is sometimes used as a distinctive attribute for virus classification to the genus level $(16,22)$.

Four categories (nonpersistent, semipersistent, persistent-circulative, and persistent-replicative) have been proposed for plant viruses transmitted by insects based on the time frame at which the vector is able to inoculate the virus into a new host $(20,45)$. Nonpersistent viruses, for instance, are retained in the stylet of the insect and can be inoculated into a new host for only a short period of time. Semipersistent viruses, on the other hand, can be

Corresponding author: D. F. Quito-Avila; E-mail address: quitod@ onid.orst.edu

Mention of trade names or commercial products in this publication is solely for the purpose of providing specific information and does not imply recommendation or endorsement by the United States Department of Agriculture (USDA). The USDA is an equal opportunity provider and employer.

http://dx.doi.org/10.1094/PHYTO-12-11-0331

This article is in the public domain and not copyrightable. It may be freely reprinted with customary crediting of the source. The American Phytopathological Society, 2012. transmitted for a few hours to days, until the insect molts and the virus is shed. Persistently transmitted viruses can be inoculated for longer periods and are not lost during the insect molt. These viruses can either replicate (persistent-replicative) or circulate (persistent-circulative) in the vector before they are inoculated into a new host (13).

The family Reoviridae, the most diverse among dsRNA virus families, includes species isolated from a wide range of hosts, including mammals, birds, fish, insects, arachnids, marine protists, crustaceans, fungi, and plants $(5,7,12)$. Plant reoviruses, classified into three genera (i.e., Fijivirus, Oryzavirus, and Phytoreovirus), constitute one of the three nonenveloped virus groups that are transmitted in a persistent replicative manner by several species of planthoppers (Hemiptera: Delphacidae) (Fijivirus and Oryzavirus spp.) and leafhoppers (Hemiptera: Cicadellidae) (Phytoreovirus spp.) (13). The intricate relationship between different plant reoviruses and their respective vectors has been extensively studied. Acquisition and inoculation times required for transmission of plant reoviruses range from minutes to days (21). In addition, members of the genera Fijivirus and Phytoreovirus are capable of being transmitted transovarially to the vector progeny for several generations and retain their transmissivity for many years (15). The rates at which transovarial transmission occurs vary between viruses, with 0.2 to $17 \%$ in Fijivirus spp. and 1.8 to $100 \%$ in Phytoreovirus spp. $(13,15)$. Furthermore, the genera Fijivirus and Phytoreovirus contain members whose primary hosts are insects. Examples include Nilaparvata lugens virus, found in the brown planthopper Nilaparvata lugens (Stål), and Homalodisca vitripennis virus, isolated from the glassywinged sharpshooter $H$. vitripennis (Germar) $(24,35)$.

Raspberry latent virus (RpLV) is a reovirus found naturally in commercial raspberry fields in the Pacific Northwest (PNW) (Oregon and Washington in the United States and British Columbia in Canada) (28). The genetic characterization of RpLV re- 
vealed that the virus possesses 10 double-sided (ds)RNA segments with features typical of reoviruses, including conserved termini, inverted repeats, and highly conserved RNA-dependent RNA polymerase (RdRp) sequences $(4,5,23)$. The phylogenetic analysis grouped RpLV with members of the subfamily Spinareovirinae and showed Rice ragged stunt oryzavirus (RRSV) as its closest relative, with $36 \%$ amino acid identity of the RdRp (28).

Based on the genetics of RpLV, it was reasonable to consider leafhoppers as potential vectors of the new reovirus. In efforts to identify the vector and determine the transmission biology of RpLV, the brambleberry leafhopper Macropsis fuscula (Zetterstedt) was collected from raspberry plants in Oregon and used for transmission experiments. M. fuscula is the only leafhopper species reported as a potential vector of viruses, or other infectious diseases, in the PNW $(33,38)$. However, the insect is barely observed in raspberry commercial areas in Washington and Oregon and, therefore, has not been considered a problem by growers ( $R$. Martin, personal communication). Repeated trials using both adults $(n=85)$ and nymphs $(n=45)$ of M. fuscula and two other hopper species collected in sweep nets, the potato leafhopper Empoasca fabae (Harris) $(n=60)$ and the spittlebug Philaenus spumarius (L.) $(n=40)$, failed to inoculate RpLV into a new host after several days of virus acquisition (D. Quito-Avila, unpublished data). The amplification of a 683-bp fragment from the highly conserved insect actin gene indicated that the RNA extraction and reverse-transcription (RT) reactions were in good conditions, validating the negative results obtained for the virus acquisition (34).

The high incidence of populations of the large raspberry aphid Amphorophora agathonica Hottes (Hemiptera: Aphididae) in northern Washington State, where RpLV is common (28), suggested the potential involvement of A. agathonica as the vector of RpLV.

This article reports the successful host-to-host transmission of RpLV by A. agathonica. To our knowledge, this is the first plant reovirus transmitted by a hemipteran vector that does not belong to the families Cicadellidae or Delphacidae. This unique biological characteristic makes RpLV the type member of a new genus that includes plant reoviruses transmitted by aphids.

\section{MATERIALS AND METHODS}

Aphid colonies and virus source. Aphids (A. agathonica) were obtained from young raspberry plants in commercial areas in Whatcom County, WA in June 2010. Upon collection, aphids from different plants and fields were consolidated, subsampled, and tested for RpLV by RT-polymerase chain reaction (PCR) to verify their virus-free status. Aphids were reared at $23^{\circ} \mathrm{C}$ and $14 \mathrm{~h}$ of light on dsRNA-free 'Meeker' raspberry obtained from tissue culture at the United States Department of Agriculture-Agricultural Research Service Horticultural Crops Research Laboratory in Corvallis, OR. Apterous (wingless) adult aphids were used in experiments unless otherwise noted. Two raspberry plants, one singly infected with RpLV alone and the second infected with RpLV and Raspberry leaf mottle virus (RLMV), were used as virus sources for transmission experiments. RLMV, a closterovirus, has been shown to be present at high incidence in commercial raspberry areas in the PNW $(30,41)$. Thus, its role in the transmission of RpLV was investigated. However, due to an unpredicted problem with the 2010 colony, the transmission experiment using the mixed-infected (RpLV-RLMV) plant as virus source was conducted with a new aphid colony collected in July 2011.

RNA extraction and RT-PCR. Total RNA was extracted from plants or aphids as described by Halgren et al. (11), followed by resuspension in $500 \mu \mathrm{l}$ of wash buffer and $25 \mu \mathrm{l}$ of glass milk (15 $\mu$ l for single aphids) (30). The glass milk was pelleted at $1,400 \times g$, washed, and dried in a speed vac at room temperature.
Then, $150 \mu \mathrm{l}$ of Tris-EDTA (100 $\mu \mathrm{l}$ for individual aphids) was used to resuspend the RNA. RT was performed using $2.5 \mu \mathrm{l}$ of plant or aphid RNA as template and random primers as described (11). The RT product $(2.5 \mu \mathrm{l})$ was used as template for the PCR in a final volume of $25 \mu \mathrm{l}$. The reaction was carried out according to the polymerase manufacturer's instructions (TaKaRa Bio Inc., Shiga, Japan). RNA quality and effectiveness of the RT reaction from aphid RNA was verified by the amplification of a 683-bp transcript region of the actin by primers Act-2F (5'-ATGG TCGGYATGGGNCAGAAGGAC-3') and Act8-R (5'-GATTCCA TACCCAGGAAGGADGG-3') (34), whereas the highly conserved plant gene NADH dehydrogenase ND2 subunit (ndhB) was used as endogenous control to verify the RNA quality and RT reaction by amplification of a 721-bp transcript region $(36,41)$. RpLV was detected by conventional RT-PCR using the primers described in Quito-Avila et al. (28). The PCR program consisted of initial denaturation for $4 \mathrm{~min}$ at $94^{\circ} \mathrm{C}$; followed by 40 cycles with a denaturation step of $40 \mathrm{~s}$ at $94^{\circ} \mathrm{C}$, annealing for $25 \mathrm{~s}$ at $58^{\circ} \mathrm{C}(\mathrm{RpLV}$ and $\mathrm{ndhB})$ or $52^{\circ} \mathrm{C}$ (actin), and extension for $40 \mathrm{~s}$ at $72^{\circ} \mathrm{C}$; with a final 7-min extension step at $72^{\circ} \mathrm{C}$.

Quantitative and standardization. The titer of RpLV in single aphids was monitored over time by TaqMan quantitative (q)RTPCR. A standard curve was generated as described by Quito-Avila et al. (29) using a T7 promoter sequence attached to the $5^{\prime}$ end of the forward primer $5^{\prime}$-CCGAGAGTGTTTGTTACG-3'. The reverse primer 5'-CGTTCCCTGTAAACGCTGCACTGTCG-3' was developed to amplify a 315-nucleotide (nt) region of the RdRp, which encloses a 131-nt region amplified by qRT-PCR primers RpLVF-5'-GGGACGTATTTCGCTTCTCAG-3' and RpLVR-5'GGGTCTGCCTCTAATGTTATGG- ${ }^{\prime}$ and the probe $5^{\prime}$-AGCA TGATCACTGGTCTTAACGCCG-3'.

A 10-factor serial dilution was prepared that resulted in concentrations of $8 \times 10^{12}$ to $8 \times 10^{1}$ targets resuspended in RNA extracts from virus-free raspberry plants or virus-free aphids. Each serial dilution series was used in triplicate. The plotted curve (threshold values $[C t]$ versus number of RNA copies) was used to extrapolate subsequent tests and estimate the number of targets from aphids. In addition, the comparative quantification method $(\Delta \Delta C t)$ was implemented to obtain relative quantification (RQ) values. This method adjusts variations in total RNA abundance in the sample by normalizing the amplification of each target to an endogenous control (17). Primers for quantitative amplification of the aphid actin gene were used in this study as described by Quito-Avila et al. (29).

Acquisition and transmission preliminary experiments. Two preliminary experiments were implemented to determine the optimal virus acquisition access period (AAP) and number of aphids needed for RpLV transmission to occur. This and all subsequent transmission experiments were conducted under controlled conditions $\left(23 \pm 1{ }^{\circ} \mathrm{C}\right.$ and $14 \mathrm{~h}$ of light). For the first experiment, $20 \mathrm{RpLV}$-free adult aphids were allowed virus AAPs of $12 \mathrm{~h}$, $18 \mathrm{~h}, 1$ day, and 2 days. The aphids were ground and tested immediately after each AAP was completed. The second experiment consisted of groups of 5, 15, 25, and 50 adult aphids which were allowed to feed on a virus-infected plant for a fixed AAP of 7 days. Upon virus acquisition, each group of aphids was transferred to RpLV-free plants (the experiment was conducted in triplicate). Inoculated plants were tested for RpLV 30, 60, 90, and 120 days postinoculation (DPI).

To determine how long and in what tissues aphids needed to feed before acquiring RpLV, aphid feeding behavior was monitored using an electrical penetration graph (EPG) system $(37,44)$. Adult aphids were starved for $1 \mathrm{~h}$, during which time they were immobilized and connected to flexible gold wire $(25.4 \mu \mathrm{m})$ with conductive glue (1:1:1, craft glue/silver flake/water by weight). The other end of the wire was connected into an AC-DC EPG system (6). A second copper electrode was inserted into the soil at the base of Meeker infected with RpLV. Direct current (DC) was 
applied at $50 \mathrm{mV}$ to the plant and data was collected using a Giga-Ohm $\left(10^{\wedge} 9\right)$ input resistor at a sample rate of $100 \mathrm{~Hz}$. EPG recordings were acquired using a DI-710 and Windaq Acquisition Software (Dataq Instruments Inc., Akron, OH). Aphids were recorded for $24 \mathrm{~h}$ and subsequently maintained on healthy Meeker for 5 days before being tested for the virus by RT-PCR or qRTPCR. EPG recordings were imported into the Windaq Waveform Browser (Dataq Instruments Inc.) and each waveform event (uninterrupted feeding behavior) was scored as $\mathrm{C}$ (penetration in mesophyll and epidermis, including cell punctures), E1 (salivation into phloem sieve elements), E2 (ingestion of phloem sap), or G (ingestion of xylem).

Virus transmission in serial transfers. In total, 600 adult aphids were allowed to feed on an RpLV source raspberry plant (RpLV alone or RpLV-RLMV infected plant). Three groups of aphids (200 aphids each) were transferred from the infected plant after 1, 2, or 4 days of virus acquisition. To verify whether aphids had acquired the virus, 20 aphids from each group were individually tested by RT-PCR. The remaining aphids from each AAP group (180 aphids) were equally distributed to three healthy plants (i.e., 60 aphids per plant) and allowed inoculation access periods (IAPs) of 2 days in a serial manner for a total of 12 days (e.g., six transfers) (Fig. 1). After aphid removal, inoculated plants were maintained in the greenhouse and tested 30, 60, 90, and 120 DPI. The experiment, as depicted in Figure 1, was replicated three times.

Transmission efficiency by single aphids. In total, 80 raspberry plants were inoculated with individual viruliferous aphids (after 5 days of virus acquisition from an RpLV singly infected plant). Aphids born on each plant (clonal aphids) were separately collected and reared in microtiter wells (Falcon 24-well plates; Becton Dickinson Inc., NJ) until plants were tested for RpLV (120 DPI). In addition, a separate experiment was implemented where 120 viruliferous aphids were individually confined in microtiter wells (Falcon 24-well plates) containing leaf disks abaxial-side up. Each disk was placed on a wetted filter paper to prevent dehydration. Aphids were maintained on each disk for 4 days and transferred to a new disk for a total of three transfers.
After aphid feeding, disks were submerged in water and exposed to $12 \mathrm{~h}$ of light for 10 days as described by Wijkamp et al. (48). After this period, the disks were collected and frozen at $-80^{\circ} \mathrm{C}$ for subsequent virus testing. Aphids born on each disk were collected as described above.

The aim of this experiment was twofold; first, to obtain a transmission efficiency rate based on individual aphids, and second, to determine whether a genetic component was associated with virus transmission. The latter would be accomplished by testing clonal aphids from adult aphids responsible for transmitting the virus to either plants or leaf disks.

Transovarial transmission of RpLV. To investigate whether transovarial passage of RpLV occurs in aphids, as is the case for other reoviruses in leafhoppers (15), 24-well Falcon microtiter plates were used to confine single RpLV-carrying female adults. Each aphid was placed on a healthy leaf disk and the newly born aphids were placed on a separate healthy leaf within approximately $12 \mathrm{~h}$ of birth. After 7 days of rearing, 80 offspring and their mother were individually tested for RpLV by RT-PCR.

RpLV replication and accumulation in aphids. Adult RpLVfree apterous or alate aphids were placed on an RpLV-infected plant for virus acquisition. After a 24-h AAP, the aphids were serially transferred to healthy leaves (in petri dishes) or plants (in insect-proof cages) on a daily basis for 10 days. RpLV was quantified from individual aphids sampled at 1, 5, and 10 days postacquisition (DPA). Changes in titer were obtained by extrapolating the $C t$ values to a standard curve or using the $\Delta \Delta C t$ method (17).

Changes in $C t$ values over time were tested with analysis of variance (Proc MIXED) (SAS Inc., Cary, NC). Differences between treatments were tested using Fisher's least significant difference. Aphids that tested negative for the virus were not considered in the statistical analysis.

\section{RESULTS}

Acquisition and transmission of RpLV. RpLV was detected in 55 and $80 \%$ of the aphids after the $24-$ and 48 -h AAP, respectively

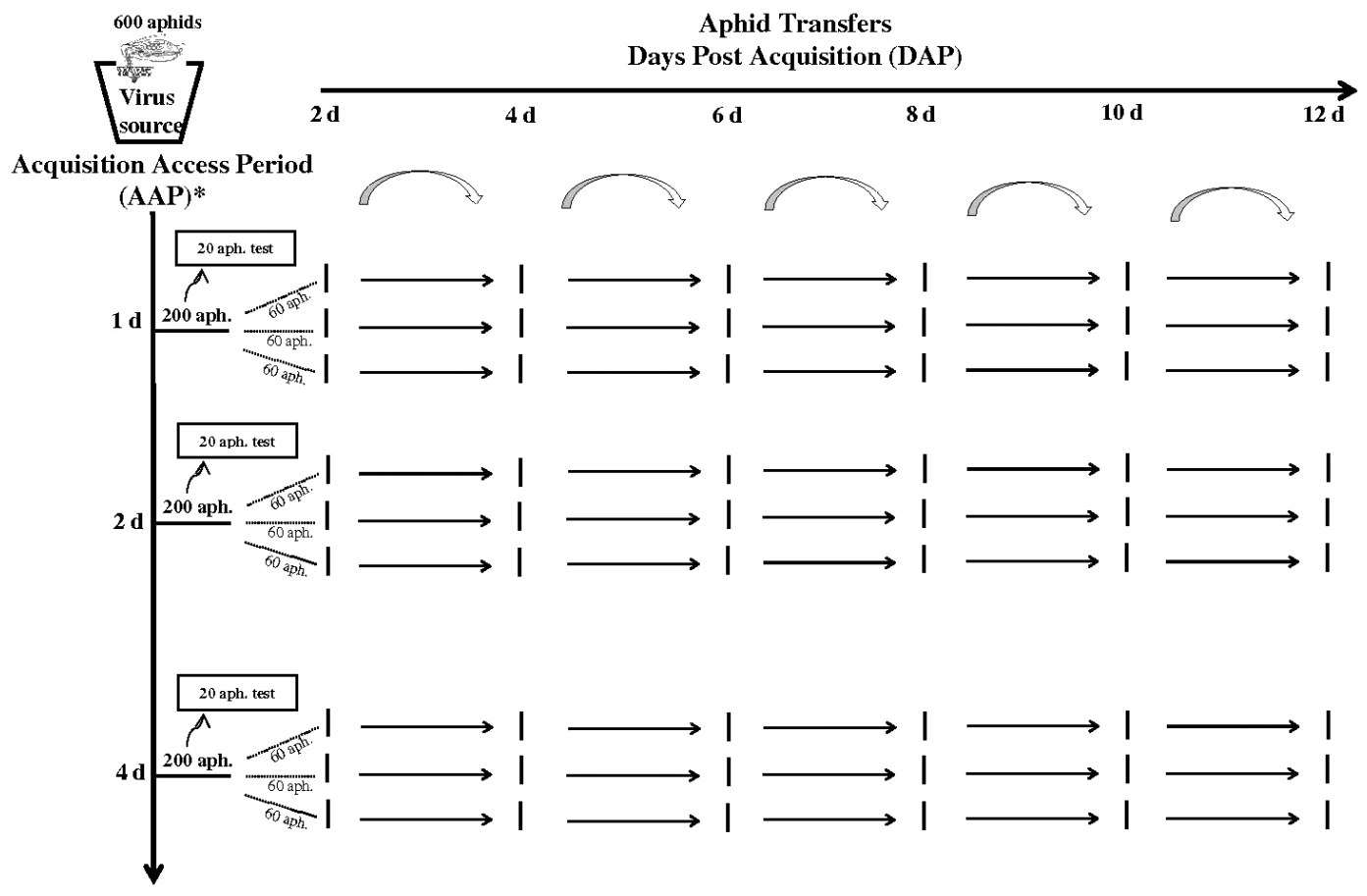

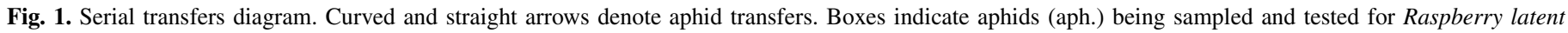

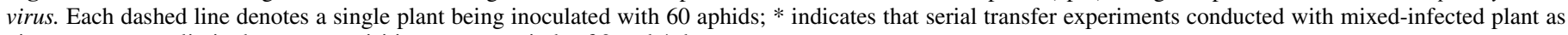
virus source were limited to two acquisition access periods of 2 and 4 days. 
(data not shown). One of three plants inoculated with 50 aphids tested positive for RpLV 90 DPI, whereas none of the plants inoculated with 5,15 , or 25 viruliferous aphids tested positive for RpLV at 120 DPI. At that point, plants were considered RpLV free.

Aphids monitored with EPG were observed to ingest from both the xylem ( $\mathrm{G}$ behavior) and phloem (E2 behavior) sap, although some individuals probed only in the mesophyll ( $\mathrm{C}$ behavior). No aphids that showed $\mathrm{G}(n=21)$ or $\mathrm{C}(n=16)$ behaviors tested positive for RpLV. Of the aphids that showed E2 waveforms $(n=$ 42), $50 \%$ tested positive for RpLV. The shortest time required for RpLV acquisition was $15 \mathrm{~min}$ of phloem ingestion, which was achieved by two aphids. However, acquisition was variable, with some aphids feeding for up to $4 \mathrm{~h}$ testing negative for the virus (data not shown).

Serial transfers. RpLV was transmitted to $1.9,5.5$, and $9.2 \%$ of the plants inoculated with 60 aphids that fed on the singly infected plant for 1,2 , and 4 days, respectively (Table 1). For AAPs of 1 and 2 days, transmission occurred in plants inoculated 8 to 10 days after virus acquisition (aphid transfers 4 and 5). Interestingly, two of the five plants that became infected after the 4-day AAP belonged to the transfer group 3 (4 to 6 days after virus acquisition). This may be due to inoculation of virus particles that had been acquired during the first 2 days of the acquisition period. Detection of the virus by RT-PCR was achieved at 90 DPI in five of the nine plants that became infected, whereas the remaining four plants tested positive at $120 \mathrm{DPI}$.

No significant differences were observed when virus inoculations were done with aphids (2011 colony) that acquired RpLV from the mixed-infected plant. RpLV was transmitted to 2.7 and $8.3 \%$ of the plants inoculated with aphids allowed AAPs of 2 and 4 days, respectively (Table 1 ). Similarly, transmission occurred in plants inoculated 8 to 10 days after virus acquisition.

Transmission efficiency and transovarial passage of RpLV to new generations of aphids. RpLV could not be detected in any of the 80 plants or 120 leaf disks inoculated with individual viruliferous aphids. None of the 80 newly born aphids, whose mothers tested positive for the virus, tested positive for RpLV after 7 days of rearing. The amplification of the 683-bp actin fragment confirmed the quality of the RNA and RT reaction, validating the results.

RpLV replication in aphids. Six experiments were conducted and analyzed separately. Absolute quantification of RpLV (experiments 1 and 2) did not show significant differences $(\alpha>0.05)$ in virus titer when aphids were tested and compared at 1,5 , and 10 DPA. However, the relative quantification method $(\Delta \Delta C t)$ showed significant differences in virus accumulation at 5 and 10 DPA in three of the four conducted experiments (experiments 4, 5, and 6) (Table 2). The increase in virus accumulation with respect to titer levels observed at 1 DPA was 11.4- to 14.1-fold at 5 DPA. Interestingly, the titer levels at 10 DPA were highly variable, with RQ values of 0.3 (i.e., 0.3 times less than the titer observed at 1 DPA) to 24.3 (i.e., 24.3 times more virus than the observed at 1 DPA). The $P$ values associated with each experiment along with the relative increase (or decrease) in virus titer over time are shown in Table 2.

\section{DISCUSSION}

Vector-mediated transmission of plant viruses is a very specific biological process. Successful transmission of a virus by its vector is dependent on a series of intricate host-virus interactions from virus acquisition to virus inoculation. The complexity of this process is increased in viruses transmitted in a persistent manner (13) and even more so in propagative transmission, where the virus infects the vector as well as the plant host. This is due to the existence of longer pathways that involves interactions between virus-encoded proteins and vector components $(9,14,20,26$, $45,47)$. Here, it has been shown that the large raspberry aphid $A$. agathonica can transmit RpLV, a new plant reovirus, in a persistent replicative manner.

Thus far, all known plant reoviruses have been reported to be transmitted by vectors in the family Cicadellidae (Phytoreovirus spp.) or Delphacidae (Oryzavirus and Fijivirus spp.). The unique-

TABLE 1. Summary of three separate experiments of aphid transmission ${ }^{\mathrm{y}}$

\begin{tabular}{|c|c|c|c|c|c|c|c|}
\hline \multirow[b]{2}{*}{ Virus source, AAPz } & \multicolumn{6}{|c|}{ Days after virus acquisition } & \multirow[b]{2}{*}{$\begin{array}{c}\text { Total infected } \\
\text { plants }(\%)\end{array}$} \\
\hline & $\begin{array}{c}\text { Transfer } 1 \\
\text { (2 days) }\end{array}$ & $\begin{array}{c}\text { Transfer } 2 \\
\text { (4 days) }\end{array}$ & $\begin{array}{c}\text { Transfer } 3 \\
\text { (6 days) }\end{array}$ & $\begin{array}{c}\text { Transfer } 4 \\
\text { (8 days) }\end{array}$ & $\begin{array}{c}\text { Transfer } 5 \\
\text { (10 days) }\end{array}$ & $\begin{array}{l}\text { Transfer } 6 \\
\text { (12 days) }\end{array}$ & \\
\hline \multicolumn{8}{|l|}{ Single infection } \\
\hline 1 day & $0 / 9$ & $0 / 9$ & $0 / 9$ & $1 / 9$ & $0 / 9$ & $0 / 9$ & $1(1.8)$ \\
\hline 2 days & $0 / 9$ & $0 / 9$ & $0 / 9$ & $2 / 9$ & $1 / 9$ & $0 / 9$ & $3(5.5)$ \\
\hline 4 days & $0 / 9$ & $0 / 9$ & $2 / 9$ & $2 / 9$ & $1 / 9$ & $0 / 9$ & $5(9.2)$ \\
\hline \multicolumn{8}{|l|}{ Mixed infection } \\
\hline 2 days & $0 / 6$ & $0 / 6$ & $0 / 6$ & $0 / 6$ & $1 / 6$ & $0 / 6$ & $1(2.7)$ \\
\hline 4 days & $0 / 6$ & $0 / 6$ & $0 / 6$ & $1 / 6$ & $2 / 6$ & $0 / 6$ & $3(8.3)$ \\
\hline
\end{tabular}

y Plants that became infected with Raspberry latent virus (RpLV) are shown in bold.

${ }^{\mathrm{z}} \mathrm{AAP}=$ acquisition access period. Note that only two AAPs were tested with aphids that acquired RpLV from the mixed-infected plant.

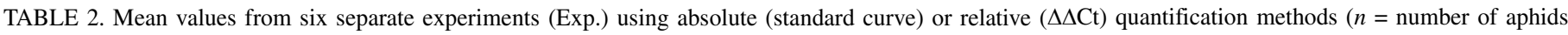
used in the experiment) $)^{\mathrm{y}}$

\begin{tabular}{|c|c|c|c|c|c|c|}
\hline \multirow[b]{3}{*}{$\mathrm{DAP}^{z}$} & \multicolumn{6}{|c|}{ Method, quantification values } \\
\hline & \multicolumn{2}{|c|}{ Standard curve, number of amplified copies } & \multicolumn{4}{|c|}{ Relative $\Delta \Delta \mathrm{Ct}$, relative quantification } \\
\hline & Exp. $1(n=27)$ & Exp. $2(n=36)$ & Exp. $3(n=36)$ & Exp. $4(n=27)$ & Exp. $5(n=12)$ & Exp. $6(n=54)$ \\
\hline 1 & $3.04 \mathrm{E}^{9}$ & 490,126 & 1 & $1 \mathrm{a}$ & $1 \mathrm{a}$ & $1 \mathrm{a}$ \\
\hline 5 & $3.01 \mathrm{E}^{9}$ & 528,183 & 11.4 & $12.7 \mathrm{~b}$ & $14.1 \mathrm{c}$ & $11.4 \mathrm{~b}$ \\
\hline 10 & $3.19 \mathrm{E}^{9}$ & 517,808 & 28.2 & $0.3 \mathrm{a}$ & $6.2 \mathrm{~b}$ & $24.3 \mathrm{~b}$ \\
\hline$P$ value $(\alpha=0.05)$ & 0.06 & 0.38 & 0.35 & 0.02 & 0.0007 & 0.02 \\
\hline
\end{tabular}

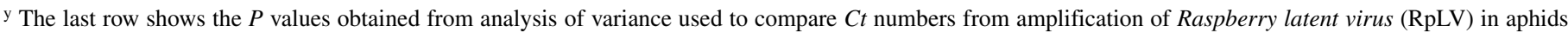
at different days postacquisition (DPA). Relative quantification (RQ) values indicate fold-increase (RQ values $>1)$ or fold-decrease (RQ values $<1)$ observed for RpLV in aphids at 5 and 10 DPA with respect to the concentration of RpLV in aphids at 1 DPA (e.g., RQ $=1)$. Letters after the RQ values signify differences in RQ between DAPs within the same experiment.

${ }^{z}$ Days postacquisition. 
ness of the transmission biology of RpLV is supported by its genetic analysis, which revealed that the conserved terminal regions of its 10 genomic segments are not fully homologous to any of the conserved termini reported for the three genera of plant reovirus. Partial conservation at the $5^{\prime}$ end was observed with members of the genus Fijivirus only, whereas the last three nucleotides of RpLV showed homology to members of the genus Orbivirus, which includes animal-infecting viruses (28). The conservation of the terminal nucleotides has been considered a determinant factor for the classification of reoviruses at the genus level $(4,5)$. Hence, the genus Raslavirus (from Raspberry latent virus) is proposed for the classification of plant reoviruses genetically related to $\mathrm{RpLV}$ that are transmitted by aphids.

While this communication was being prepared, two new reoviruses, Spissistilus festinus reovirus (SpFRV) and Acinopterus angulatus reovirus (AcARV), were identified from the threecornered alfalfa hopper Spissistilus festinus Say and the angulate leafhopper Acinopterus angulatus Lawson, respectively. SpFRV and AcARV are related closely to each other, with 39\% RdRp amino acid identity and similar terminal sequences (32). Phylogenetic analysis showed that SpFRV, AcARV, RRSV, and RpLV constitute a clade within the subfamily Spinareovirinae (32). However, our analyses suggest the existence of three distinct lineages within this subfamily (Fig. 2). The first, represented by extant members of the genus Oryzavirus (RRSV); the second, constituted by SpFRV and AcARV as a possible new genus as proposed by Spear et al. (32); and the third, typified by RpLV, the putative type species of a new genus (Raslavirus) of dicotinfecting reoviruses. This scenario is supported by the recent discovery of a new reovirus from native Vitis aestivalis collected from Great Smoky Mountains National Park in the United States (31). The sequence of the virus has not yet been published but exchange of sequences revealed that this virus is related most closely to RpLV, sharing identical terminal sequences, highly conserved amino acid content in the RdRp gene, and a dicotyledonous host (S. Sabanadzovic, personal communication). Thus, RpLV has molecular, phylogenetic, and epidemiological (vector and host) properties clearly distinct from the extant reoviruses, justifying the proposal for the establishment of a new genus in the subfamily Spinareovirinae of the Reoviridae.

The efficiency at which RpLV was transmitted by A. agathonica was very low. Repeated attempts to transmit the virus by single aphids did not result in infected plants. Low rates of virus transmission were obtained only when groups of at least 50 aphids per plant were used. Experiments conducted to test the possibility of RpLV being transmitted at higher efficiency when acquired from plants co-infected with RLMV, commonly found in mixed infections (RLMV-RpLV) in the field $(29,40)$, did not show significant differences in transmission rates (Table 1).

qRT-PCR showed that the titer of RpLV increased in aphids that were allowed an AAP of $24 \mathrm{~h}$ and transferred immediately to healthy leaves. Three of the six separate qRT-PCR experiments conducted in this study showed significant $(P<0.05)$ changes in virus accumulation at 5 and 10 DPA compared with virus titers at 1 DPA. Whereas two of those experiments showed increases of 6.3- to 24-fold at $10 \mathrm{DPA}$, one experiment showed a 0.3 -fold decrease compared with the titer observed at 1 DPA (Table 2). The odd decrease in virus titers along with the nonsignificant results from the other three experiments was mainly due to the high variation observed across single aphids, especially after 5 DPA, where some aphids showed large increases whereas a few others showed declined levels of virus titers. The large variability in the apparent replication of RpLV in individual aphids may suggest a precarious adaptation to a new vector. Persistently transmitted

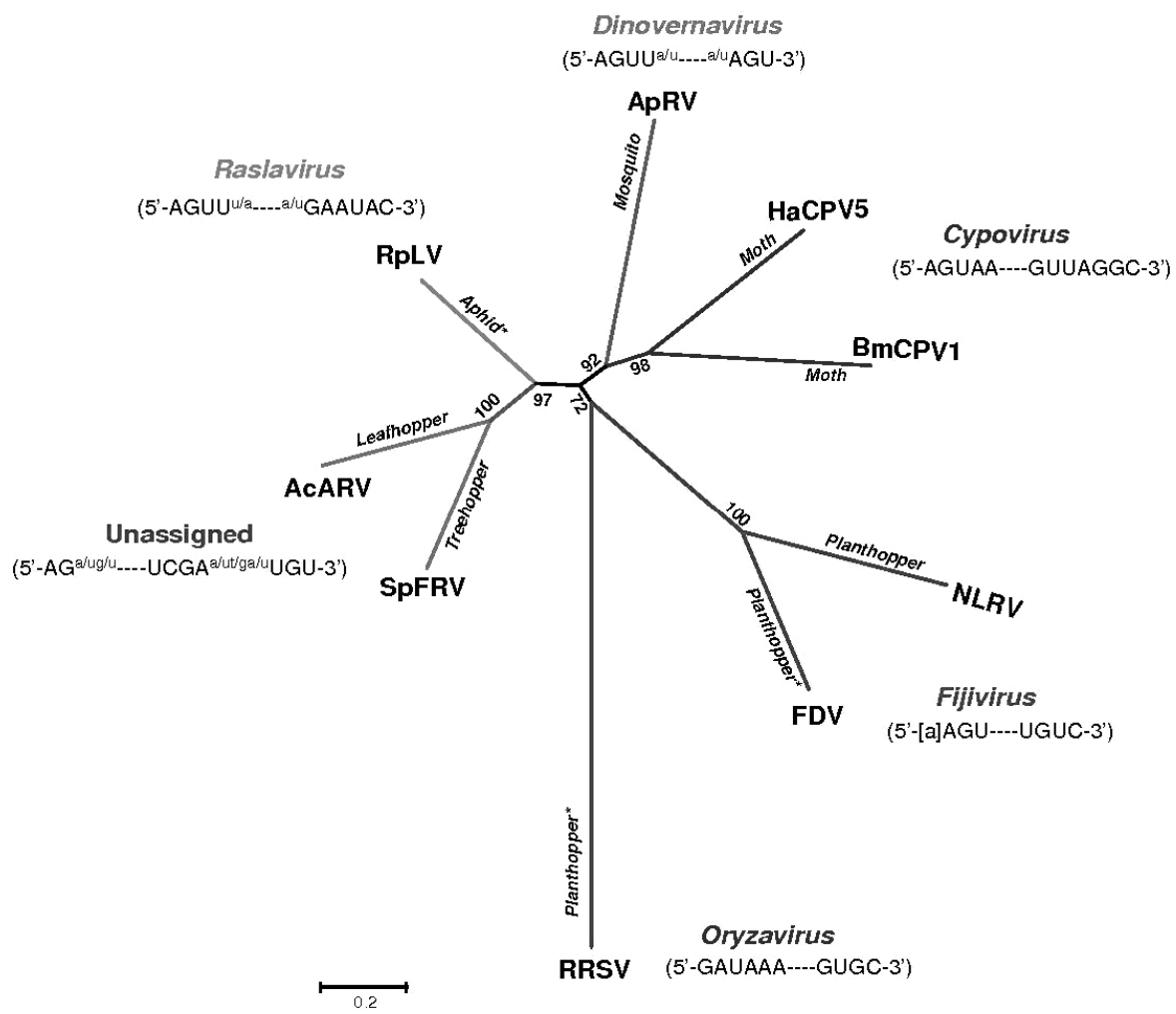

Fig. 2. Maximum parsimony phylogenetic tree showing host and vector diversity of Reovirus spp. of the subfamily Spinareovirinae closest to Raspberry latent virus (RpLV). Bootstrap values (1,000 replications) are shown at each node. The following virus species, with the corresponding GenBank accession, were included in the analysis: RpLV (HQ012655), Spissistilus festinus reovirus (SpFRV; JF773383), Acinopterus angulatus reovirus (AcARV; JN792199), Rice ragged stunt virus (RRSV; NP_620541), Aedes pseudoscutellaris reovirus (ApRV; YP_443936), Bombyx mori cypovirus 1 (BmCPV1; AAR88092), Heliothis armigera cypovirus 5 (HaCPV5; YP_001883321); Nilaparvata lugens reovirus (NLRV; BAA08542), and Fiji disease virus (FDV; NP_619776). Conserved terminal nucleotide sequences are shown below each italicized genus. Insect species identified as hosts or vectors (insect vector denoted by asterisk) for each virus taxon are shown parallel to each branch. 
viruses (including replicative and circulative) have been shown to encounter at least three barriers that challenge the success of their replication, circulation, or transmission: (i) midgut infection and escape, (ii) survival in the hemolymph and salivary gland infection, and (iii) salivary gland escape (1). Each barrier represents a bottleneck which reduces significantly the efficiency at which a virus is transmitted to a new host. In RpLV, these obstacles may be related to age or other physiological aspects of the aphid, which also may account for some of the variation in virus titers in aphids.

The lack of an effective mechanism that protects the virus from degradation (i.e., association with endosymbiotic bacteria in the aphid gut) $(18,19)$ may also explain the inconsistencies found in the concentration of RpLV in aphids. Several studies have shown a direct interaction between viral coat proteins and the chaperonin GroEL, produced by symbiotic bacteria in aphids and other hemipterans. This interaction results in complexes that allow the virus to avoid degradation in the gut tissue and hemolymph $(18,19,42,43)$. Electron microscopy applied to aphid ultrathin sections failed to detect aggregate structures characteristic of replication complexes in epithelial gut cells in replicative viruses (D. Quito-Avila, unpublished data). Therefore, it is not clear whether RpLV interacts with the bacterial symbionin of $A$. agathonica or other vector components to result in replicative inclusion bodies. Another plausible explanation for the high variability of RpLV in aphids would be the initial amount of virus acquired by the aphid. The titer of RpLV may vary considerably depending on the leaf, and even within the leaf, where each aphid feeds.

The low transmission efficiency of RpLV by A. agathonica observed under controlled experiments was supported by data from the field. An average of $40 \%$ of raspberry plants in fields with high aphid populations and incidence of RpLV and RLMV became infected with RLMV but not RpLV by the end of the second year (D. Lightle, unpublished data). The significance of this finding from a virus management standpoint is noteworthy. Quito-Avila (27) has shown an increase in the severity of crumbly fruit disease in Meeker red raspberry co-infected with Raspberry bushy dwarf virus and RpLV. The low transmission rate and long latent period necessary for RpLV to be transmissible may be advantageous to growers, because they could reduce virus incidence and crumbly fruit severity by implementing an effective vector control program.

In summary, RpLV is the first plant reovirus transmitted by aphids (A. agathonica), albeit with a low efficiency rate. Transmission and genetic features support the classification of RpLV in a proposed new genus (Raslavirus). Virus accumulation in aphids was variable and seemed to be aphid dependent. More research is needed to elucidate the details of the virus-vector interactions at the molecular level. However, this communication reports important aspects of the transmission biology of RpLV which are key for understanding the epidemiology of virus-caused diseases and developing control measures to reduce virus spread in crop plants $(3,20,39)$.

\section{ACKNOWLEDGMENTS}

This work was partially funded by the United States Department of Agriculture under the Specialty Crops Research Initiative (SCRI), award number 2009-51181-06022, CRIS 5358-22000-032-00D. We thank N. Mosier, North American Plants Inc., and Sakuma Brothers Farm for donating plant material; I. Tzanetakis for proofreading the article; and S. Sabanadzovic and D. Stenger for sharing unpublished data on new reoviruses.

\section{LITERATURE CITED}

1. Ammar, E. D. 1994. Propagative transmission of plant and animal viruses by insects: Factors affecting vector specificity and competence. Adv. Dis.
Vector Res. 10:289-332.

2. Ammar, E. D., Tsai, C. W., Whitfield, A. E., Redinbaugh, M. G., and Hogenhout, S. A. 2009. Cellular and molecular aspects of rhabdovirus interactions with insect and plant hosts. Annu. Rev. Entomol. 54:447-468.

3. Andret-Link, P., and Fuchs, M. 2005. Transmission specificity of plant viruses by vectors. J. Plant Pathol. 87:153-165.

4. Anzola, J. V., Xu, Z., Asamizu, T., and Nuss, D. L. 1987. Segment specific inverted repeats found adjacent to conserved terminal sequences in Wound tumor virus genome and defective interfering RNAs. Proc. Natl. Acad. Sci. USA 84:8301-8305.

5. Attoui, H., Mertens, P. P. C., Becnel, J., Belaganahalli, S., Bergoin, M., Brussaard, C. P., Chappell, J. D., Ciarlet, M., del Vas, M., Dermody, T. S., Dormitzer, P. R., et al. 2012. Reoviridae. Pages 541-630 in: Virus Taxonomy: Ninth Report of the International Committee on Taxonomy of Viruses. A. M. Q. King, M. J. Adams, E. B. Carstens, and E. J. Lefkowitz, eds. Elsevier/Academic Press.

6. Backus, E. A., and Bennett, W. H. 2009. The AC-DC correlation monitor: New EPG design with flexible input resistors to detect both $\mathrm{R}$ and emf components for any piercing-sucking hemipteran. J. Insect Physiol. 55:869-884.

7. Brussaard, C. P., Noordeloos, A., Sandaa, R., Hedal, M., and Bratbak, G. 2004. Discovery of a dsRNA virus infecting the marine photosynthethic protist Micromonas pusilla. Virology 319:280-291.

8. Campbell, R. N. 1996. Fungal transmission of plant viruses. Annu. Rev. Phytopathol. 34:87-108.

9. Gray, S., and Gildow, F. E. 2003. Luteovirus-aphid interactions. Annu. Rev. Phytopathol. 41:539-566.

10. Gray, S. M., and Banerjee, N. 1999. Mechanisms of arthropod transmission of plant and animal viruses. Microbiol. Mol. Biol. Rev. 63:128148 .

11. Halgren, A., Tzanetakis, I. E., and Martin, R. R. 2007. Identification, characterization, and detection of Black raspberry necrosis virus. Phytopathology 97:44-50.

12. Hillman, B. I., Supyani, S., Kondo, H., and Suzuki, N. 2004. A Reovirus of the fungus Cryphonectria parasitica that is infectious as particles and related to the Coltivirus genus of animal pathogens. J. Virol. 78:892-898.

13. Hogenhout, S. A., Ammar, E. D., Whitfield, A. E., and Redinbaugh, M. G. 2008. Insect vector interactions with persistently transmitted viruses. Annu. Rev. Phytopathol. 46:327-359.

14. Hogenhout, S. A., Redinbaugh, M. G., and Ammar, E. D. 2003. Plant and animal rhabdovirus host range: A bug's view. Trends Microbiol. 11:264271.

15. Honda, K., Wei, T., Hagiwara, K., Higashi, T., and Kimura, I. 2008. Retention of Rice dwarf virus by descendants of pairs of viruliferous vector insects after rearing for 6 years. Phytopathology 97:712-716.

16. Karasev, A. V. 2000. Genetic diversity and evolution of closteroviruses. Annu. Rev. Phytopathol. 38:293-324.

17. Livak, K. J., and Schmittgen, T. D. 2001. Analysis of relative gene expression data using real-time quantitative PCR and the $2-\Delta \Delta C T$ method. Methods 25:402-408.

18. Morin, S., Ghanim, M., Sobol, I., and Czosnek, H. 2000. The GroEL protein of the whitefly Bemisia tabaci interacts with the coat protein of transmissible and nontransmissible begomoviruses in the yeast twohybrid system. Virology 276:404-416.

19. Morin, S., Ghanim, M., Zeidan, M., Czosnek, H., Verbeek, M., and van den Heuvel, J. F. J. M. 1999. A GroEL homologue from endosymbiotic bacteria of the whitefly Bemisia tabaci is implicated in the circulative transmission of tomato yellow leaf curl virus. Virology 256:75-84.

20. Nault, L. R. 1997. Arthropod transmission of plant viruses: A new synthesis. Ann. Entomol. Soc. Am. 90:521-541.

21. Nault, L. R., and Ammar, E. D. 1989. Leafhopper and planthopper transmission of plant-viruses. Annu. Rev. Entomol. 34:503-529.

22. Ng, J. C., and Falk, B. W. 2006. Virus-vector interactions mediating nonpersistent and semipersistent transmission of plant viruses. Annu. Rev. Phytopathol. 44:183-212.

23. Ni, Y., Kemp, M. C., Wang, L., and Collison, E. W. 1996. Sequence analysis of an avian reovirus defective interfering dsRNA derived from the S1 segment: Identification of sequences involved in replication and packaging. Pages 194-204 in: Proc. Int. Symp. Adenovirus and Reovirus Infections in Poultry. Rauschholzhausen, Germany.

24. Noda, H., and Nakashima, N. 1995. Non-pathogenic reoviruses of leafhoppers and planthoppers. Semin. Virol. 6:109-116.

25. Pirone, T. P., and Blanc, S. 1996. Helper-dependent vector transmission of plant viruses. Annu. Rev. Phytopathol. 34:227-247.

26. Power, A. G. 2000. Insect transmission of plant viruses: A constraint on virus variability. Curr. Opin. Plant Biol. 3:336-340.

27. Quito-Avila, D. F. 2011. Impact of Raspberry bushy dwarf virus, Raspberry leaf mottle virus and Raspberry latent virus on plant growth and fruit crumbliness in red raspberry (Rubus idaeus L)'Meeker'. Ph.D. dissertation, Oregon State University, ProQuest/UMI 82-108. 
28. Quito-Avila, D. F., Jelkmann, W., Tzanetakis, I., Keller, K., and Martin, R. R. 2011. Complete sequence and genetic characterization of Raspberry latent virus, a novel member of the family Reoviridae. Virus Res. 155:397-405

29. Quito-Avila, D. F., and Martin, R. R. 2012. Real-time RT-PCR for detection of Raspberry bushy dwarf virus, Raspberry leaf mottle virus and characterizing synergistic interactions in mixed infections. J. Virol. Methods 179:38-44.

30. Rott, M. E., and Jelkmann, W. 2001. Characterization and detection of several filamentous viruses of cherry: Adaptation of an alternative cloning method (DOP-PCR), and modification of an RNA extraction protocol. Eur. J. Plant Pathol. 107:411-420.

31. Sabanadzovic, S., and Ghanem-Sabanadzovic, N. A. 2010. Two undescribed viral species isolated from native grapevines. (Abstr.) Phytopathology 100:S2.

32. Spear, A., Sisterson, M. S., and Stenger, D. C. 2011. Reovirus genomes from plant-feeding insects represent a newly discovered lineage within the family Reoviridae. Virus Res. 163:503-511.

33. Stace-Smith, R. 1960. Current status of bramble viruses. Can. Plant Dis. 40:24-30.

34. Staley, M., Dorman, K., Bartholomay, L., Fernandez-Salas, I., Farfan-Ale, J., Lorono-Pino, M., Garcia-Rejon, J., Ibarra-Juarez, L., and Blitvich, B. 2010. Universal primers for the amplification and sequence analysis of Actin-1 from diverse mosquito species. J. Am. Mosquito Cont. Assoc. 26:214-218.

35. Stenger, D. C., Sisterson, M. S., Krugner, R., Backus, E. A., and Hunter, W. B. 2009. A new phytoreovirus infecting the glassy-winged sharpshooter Homalodisca vitripennis. Virology 386:469-477.

36. Thompson, J., Wetzel, S., Klerks, M., Vaskova, D., Schoen , C., Spak, J., and Jelkmann, W. 2003. Multiplex RT-PCR detection of four aphid-borne strawberry viruses in Fragaria spp. in combination with a plant mRNA specific internal control. J. Virol. Methods 111:85-93.

37. Tjallingii, W. F., and Prado, E. 2001. Analysis of circulative transmission by electrical penetration graphs. In: Virus-Insect-Plant Interactions. H. K. F., S. O. P., and D. J. E., eds. Academic Press, New York.

38. Tonks, N. V. 1960. Life history and behaviour of the leafhopper
Macropsis fuscula (Zett.) (Homoptera: Cicadellidae) in British Columbia. Can. Entomol. 92:707-713.

39. Tsai, C. W., Rowhani, A., Golino, D. A., Daane, K. M., and Almeida, R. P. P. 2010. Mealybug transmission of grapevine leafroll viruses: An analysis of virus-vector specificity. Phytopathology 100:830-834.

40. Tzanetakis, I. E., Halgren, A., Mosier, N., and Martin, R. R. 2007. Identification and characterization of Raspberry mottle virus, a novel member of the Closteroviridae. Virus Res. 127:26-33.

41. Tzanetakis, I. E., Postman, J. D., and Martin, R. R. 2007. Identification, detection and transmission of a new virivirus from Mentha. Arch. Virol. 152:2027-2033.

42. van den Heuvel, J. F. J. M., Bruyere, S. A., Hogenhout, V., Ziegler-Graff, V., Brault, M., Verbeek, F., van der, Wilk., and Richards, K. 1997. The Nterminal region of the luteovirus readthrough domain determines virus binding to Buchnera GroEL and is essential for virus persistence in the aphid. J. Virol. 71:7258-7265.

43. van den Heuvel, J. F. J. M., Verbeek, M., and van der Wilk, F. 1994 Endosymbiotic bacteria associated with circulative transmission of Potato leafroll virus by Myzus persicae. J. Gen. Virol. 75:2559-2565.

44. Walker, G. P. 2000. A beginner's guide to electronic monitoring of Homopteran probing behavior. In: Principles and Applications of Electronic Monitoring and Other Techniques in the Study of Homopteran Feeding Behavior. G. P. Walker and E. A. Backus, eds. Entomological Society of America, Lanham, MD

45. Watson M. A, and Roberts F. M. 1939. A comparative study of the transmission of Hyoscyamus virus 3, Potato virus $Y$ and Cucumber virus 1 by the vectors Myzus persicae (Sulz), M. circumflex (Buckton), and Macrosiphum gei (Koch). Proc. R. Soc. London Ser. B 127:543-576.

46. Watson, M. A, and Roberts, F. M. 1940. Evidence against the hypothesis that certain plant viruses are transmitted mechanically by aphids. Ann. Appl. Biol. 27:227-233.

47. Whitfield A. E, Ullman D. E, and German T. L. 2005. Tospovirus-thrips interactions. Annu. Rev. Phytopathol. 43:459-489.

48. Wijkamp, I., and Peters, D. 1993. Determination of median latent period of two tospoviruses in Frankliniella occidentalis, using a novel leaf disk assay. Phytopathology 83:986-999. 